Editorial

\title{
Experimental, Numerical and Field Approaches to Scour Research
}

\author{
Yee-Meng Chiew ${ }^{1, *(\mathbb{D})}$, Jihn-Sung Lai ${ }^{2}$ (D) and Oscar Link ${ }^{3} \mathbb{D}$ \\ 1 School of Civil and Environmental Engineering, Nanyang Technological University, \\ Singapore 639798, Singapore \\ 2 Hydrotech Research Institute/Department of Bioenvironmental Systems Engineering, National Taiwan \\ University, Taipei 10617, Taiwan; jslai525@ntu.edu.tw \\ 3 Department of Civil Engineering, Faculty of Engineering, Universidad de Concepción, \\ Concepción 403000, Chile; olink@udec.cl \\ * Correspondence: cymchiew@ntu.edu.sg
}

Received: 11 June 2020; Accepted: 17 June 2020; Published: 19 June 2020

\begin{abstract}
Scour, which represents a fascinating and complex engineering problem involving a number of physical mechanisms and interactions, has motivated a vast amount of research following different but complementary methodological approaches such as experimental, numerical, and field methods. Far from being completely understood, scour remains one of the main hazards for many structures such as bridges, submarine pipelines, offshore wind turbines, etc. Thus, scour is currently a very active field of research with important open questions that are unanswered and practical challenges to be tackled. This Special Issue aims to bridge knowledge gaps by collecting fourteen papers to provide a wide view of scour types and different research approaches, with innovative ideas and inferences.
\end{abstract}

Keywords: scour; sediment transport; research approaches

\section{Introduction}

Scour, which represents an intriguing and complex engineering problem involving many physical mechanisms and interactions, has motivated a vast amount of research following different but complementary methodological approaches such as experimental, numerical, and field methods. Notwithstanding the many research findings that can be found in published literature, the subject is far from being completely understood. Scour continues to be one of the main hazards for many structures such as bridges, submarine pipelines, offshore wind turbines, etc., as is shown in the catastrophic failure of Houfeng Bridge in September 2008 (Figure 1) and the serious scour problems downstream of the grade-control structure leading to the demise of Zhongzheng Bridge in July 2013 (Figure 2). Consequently, this subject remains a very active area of research with important unanswered questions and practical challenges that need to be resolved.

Published evidence reinforce the need for more research in other scour types besides pier and abutment scour, particularly considering the importance of the use of alternative sources of energy other than hydrocarbon, with the aim to alleviate the threat of carbon dioxide emission and climate change. With the number of wind farms built in recent years or to be built in the near future by European and Asian countries (particularly China), obtaining a comprehensive understanding of the mechanism of scour around monopiles and finding the most cost-effective scour countermeasure are particularly needed. Despite the important works done in Europe on monopile scour, e.g., Whitehouse et al. [1], the authors did not incorporate the effect of vibrations on scour. Such limitations were highlighted in a recent review paper by Fredsøe [2], who lamented such a lack of consideration in past researches. However, more recent researchers, e.g., Guan et al. [3], have begun to include this concern in monopile 
scour studies. The effect of vibrations on scour is presently still in its infancy stage, and more effort is clearly needed in this area, whether experimentally or numerically. The effect of vibrations on scour is not limited to monopiles but also submarine pipelines. Scour around submarine pipelines started with researchers working in the 2-dimensional case, in which laboratory tests were conducted in narrow flumes. The early empirical 2-dimensional pipeline scour researches [4,5] were extended to numerical studies [6,7]; and later to 3-dimensional scour; with the latter better epitomizing the prototype condition. Some of the earliest 3-dimensional works were empirically conducted by [8-10], which were supplemented by numerical studies, although some of the earlier numerical studies have not been vigorously verified due to the lack of experimental data [11]. The effect of vibration on pipelines is equally an important consideration, which also was ignored by these researchers. This effect was only seriously examined in the work of Li et al. [12], who showed how vibrations significantly amplify the scour formation process. Later works include the experimental works of [13-16].

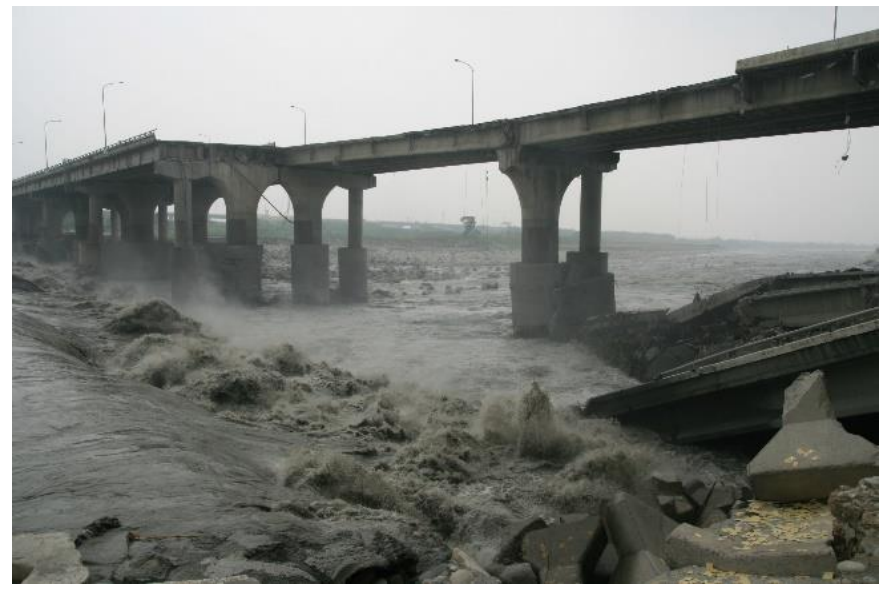

Figure 1. Failure of Houfeng Bridge in Dajia River, Taiwan due to pier-scour in September 2008 (courtesy of Yee-Meng Chiew).

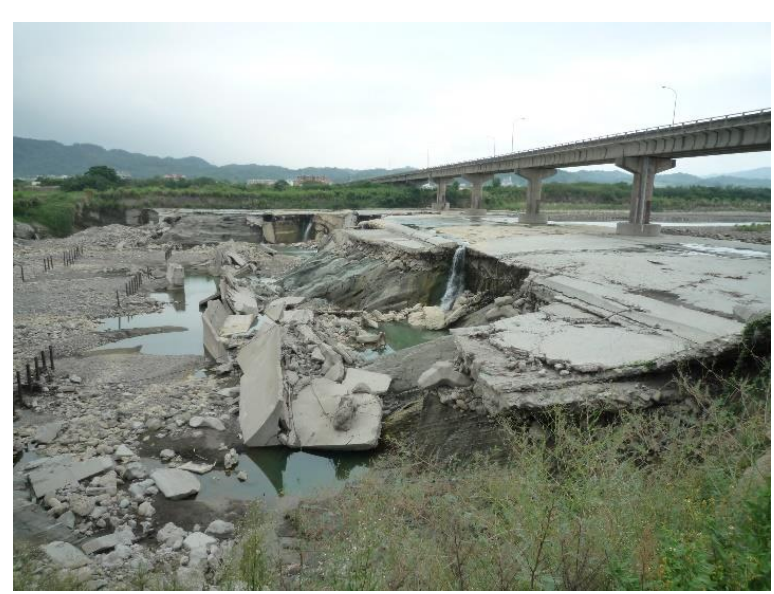

(a)

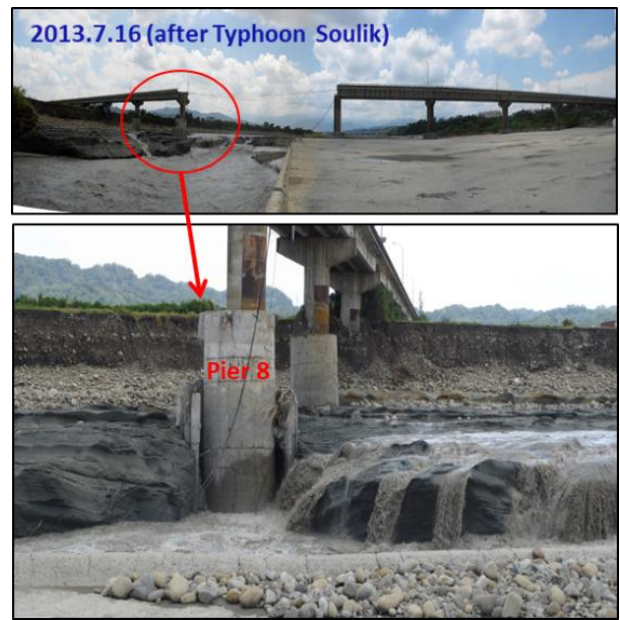

(b)

Figure 2. Scour downstream of grade-control structure leading to failure of Zhongzheng Bridge in Touqian River, Taiwan (a) scour downstream of grade-control structure in 2009 (courtesy of Yee-Meng Chiew); (b) Scour leading to bridge failure in 2013 (courtesy of Dr. Hong JH).

In comparison with pier- or even pipeline-induced scour, propeller scour receives notably less attention. Most of the earlier works were carried out in Europe, especially those conducted in Queen's University Belfast, with the first doctoral dissertation by Hamill [17] and subsequent doctoral studies. 
A second group of propeller scour works was conducted in Singapore, with very meticulous flow field measurements collected using the particle image velocimetry technique [18], giving comprehensive descriptions of the propeller-induced flow field and providing new insights into the scouring mechanism associated with the development of the scour hole. While weirs often are built along rivers, sometimes for flow regulation or as a water intake structure (as a side weir), their effects on scour have not been extensively studied. Interestingly, when the weir is very high, it essentially becomes a dam. On the other hand, if it is low, it acts similarly to a sill and eventually resembles a grade-control structure.

Reservoirs that are caused by dam construction act to impound water in rivers, mainly for water supply and flow regulation, invariably modifying the channel bed slope. Accordingly, their formation has a tendency to induce sediment deposition, which is a kind of negative scour $[19,20]$, while a grade-control structure can have a profound influence on local scour [21]. Reservoirs also interrupt the course of sediment transport through river systems, causing decreased sediment loads because of trapping by upstream dams [22,23]. The interference of sediment trapping by reservoir exerts considerable morphological effects on downstream river channels, including riverbed incisions, riverbank instabilities, scour-induced damages to infrastructure (e.g., bridges, pipeline-crossings, embankments, and levees), channel width variations, and coastal erosion. Many reservoir management strategies and effective countermeasures have been investigated to reduce sediment deposition in reservoirs and increase sediment supply for downstream river systems [24,25]. To remove trapped sediment deposits from reservoirs, mechanical dredging is one of the commonly used measures. However, the disposal of dredged sediment is costly.

From another viewpoint, dredged sediments may be considered as a resource that provides effective environmental benefits. By adding sediment to a river, an approach termed sediment replenishment or sediment augmentation can be applied to compensate for the lack of sediment loads downstream of dams. In field practice, it can be planned and practiced in specific hydrological and geographic areas. Okano et al. [26] investigated reservoir sedimentation management by depositing coarse sediment (mainly sand and gravel sizes) for downstream replenishment. The conceptual idea of the replenishment method is to place sediments on the downstream floodplain before the arrival of floods. During the flood season, the replenished sediment will be scoured and distributed downstream. The applied replenishment method requires a sufficient amount of discharge in order to scour the replenished sediment. In practice, sediment deposited in a reservoir can be periodically dredged and strategically placed on the floodplain downstream of the dam. Most commonly, the sediments added are gravel and sand obtained from gravel quarries in the floodplain or other sources. Additionally, sediments also may be dredged from the reservoir delta deposits [27,28]. Ock et al. [28] reviewed methods in the context of sediment replenishment and compared implementation activities undertaken in Japan and the USA. According to sediment placement, sediment replenishment methods are implemented with mechanical rehabilitation for re-creating gravel or sand bar features through fluvial processes. This comparative study provides useful information for engineers to adopt proper methods corresponding to river-specific high-flow and sediment regimes. Laboratory experiments and field investigations have been conducted to improve the understanding of the transport processes of sediment replenishment on the river basin scale $[29,30]$. Notwithstanding these research, additional works clearly are needed to ensure the most cost-effective solution to address the dire problems of reservoir storage and downstream bed load reduction that are prevalent worldwide presently.

The editors of this Special Issue have carefully selected fourteen papers to provide a wide view of scour types using different research approaches. We hope that the contents of these papers, which do not originate from them, will provide guidelines for practicing engineers and researchers in their works.

\section{Contributions}

This Special Issue comprises fourteen papers, the majority of which examine the scour topic from the empirical or experimental approaches $(64 \%)$; the others are founded on the numerical and field approaches, and a review paper. The types of structure involved are piers, pipelines, propellers, 
turbines, weirs, reservoirs, and grade-control structures (GCS), with piers leading the group with five papers or $36 \%$. The review paper summarizes research works to-date relating to bridge foundation, namely piers and abutments, in supercritical flows. The number of papers published in terms of the research methodology or structure type, namely experimental approach and pier scour, respectively, is representative of the number of papers most commonly found within scour research in archival journals and conference proceedings. Notwithstanding the number of published research works in a particular area, this does not negate the importance of scour research in the other areas and research approaches. The limited number of scour research using field data in this Issue highlights the need for more efforts in the field approach. The papers of this Special Issue, which are listed in alphabetical order of the lead author, are summarized as follows:

Chavan et al. Turbulent Flow Structures and Scour Hole Characteristics around Circular Bridge Piers over Non-Uniform Sand Bed Channels with Downward Seepage

This paper [31] presents the experimental results of the scour hole characteristics forming around single vertical pier sets on a non-uniform sand bed with and without downward seepage. Empirical equations for the evaluation of the scour hole characteristics such as the length, width, area, and volume, including the downward seepage parameter, are proposed and experimentally tested. Predictions give reasonably good agreement with the experimental data.

Cui et al. Scour Induced by Single and Twin Propeller Jets

The authors conduct laboratory experiments to investigate scour induced by single and twin propeller jets [32]. Propellers with three and six blades typically used in British ports and harbors are scaled according to the similitude theory and reduced propeller models were created with a $3 \mathrm{D}$ printer using biodegradable the polylactic acid filament, PLA, material. A laser rangefinder is used to measure the scour depth during the experiments. Empirical relations for the computation of the scour depth along the propeller axis are provided.

Guan et al. Scour Evolution Downstream of Submerged Weirs in Clear Water Scour Conditions

The authors propose exponential equations to estimate the temporal variation in the scour depth and scour length downstream of a submerged weir [33]. The study is useful in the development of models capable of estimating scour depth downstream of weirs in rivers or coastal areas, for which the overtopping conditions are very common. The proposed equations for scour hole dimensions, profiles, and sizes will be good tools for hydraulic engineers in the design of scour countermeasures.

Lee et al. Scouring of Replenished Sediment through Reservoir Flood Discharge Affects Suspended Sediment Concentrations at Downstream River Water Intake

This paper describes a comprehensive study on the transport of replenished sediment following two methodological approaches, namely numerical modelling and physical scale modelling [34]. Valuable field data are used for the models' calibrations and validations. The study makes an important contribution to the use of dredged reservoir sediments focusing on fine (cohesive) sediments for sediment replenishment, which in turn contributes to the morphological stability of the river downstream a dam. In this way, an alternative for the disposal of dredged fine sediments taking advantage of scour is provided.

Lin et al. Visible Light Communication System for Offshore Wind Turbine Foundation Scour Early Warning Monitoring

This paper proposes a scour monitoring system for offshore wind turbine installations using visible light communication (VLC) modules [35]. The feasibility of the proposed system is investigated through laboratory scour experiments. The novel technique is a promising low-cost alternative for field scour monitoring.

Link et al. Scour at Bridge Foundations in Supercritical Flows: An Analysis of Knowledge Gaps

Scour at bridge foundations, viz., piers and abutments caused by supercritical flows, is reviewed and knowledge gaps are identified and discussed [36]. Based on published data, the review paper finds that the scour depth caused by supercritical flows is unexpectedly much lower than that found 
in subcritical flows, and argues that the reasons of this behavior remain uncertain. It surmises that interactions of the horseshoe vortex with the detached hydraulic jump and the wall jet flow observed in supercritical flows could be a reason. Finally, it provides recommendations for future research in this topic.

Ma et al. Case Study: Model Test on the Effects of Grade Control Datum Drop on the Upstream Bed Morphology in Shiting River

This case study describes the construction of a 1:80 undistorted physical model of a $1.3 \mathrm{~km}-\mathrm{long}$ river reach in Shiting River, China, to investigate the impact of the grade-control datum (GCD, which is defined as the crest elevation of the grade-control structure) on the upstream bed morphology [37]. It provides a plausible designed consideration for the solution of scour countermeasure against excessive erosion around an existing bridge on the river.

Mathieu et al. Two-Phase Flow Simulation of Tunnel and Lee-Wake Erosion of Scour below a Submarine Pipeline

This paper presents a numerical investigation of the scour phenomenon around a submarine pipeline [38]. Numerical simulations are performed using a two-phase flow model for sediment transport implemented in an open-source computational fluid dynamics (CFD) toolbox. The paper focuses on the sensitivity of the granular stress model and the turbulence model with respect to the predictive capability of the two-phase flow model. The numerical results show no sensitivity to the granular stress model. However, the results are strongly dependent on the choice of turbulence model.

Quezada et al. Numerical Study of the Hydrodynamics of Waves and Currents and Their Effects in Pier Scouring

The authors use the Reynolds averaged Navier-Stokes (RANS) equations via REEF3D numerical modeling to simulate the hydrodynamic field and estimate the scour around cylindrical piles due to co-directional and opposite waves and currents [39]. The relative velocity of a current is defined as an indicator that adequately measures the interactions between currents and waves under the condition of co-directional flows. It concludes that the dimensionless scour depth will be less when waves and currents come from opposite directions.

Sun et al. Temporal Evolution of Seabed Scour Induced by Darrieus-Type Tidal Current Turbine

This paper presents an experimental study on the temporal evolution of seabed scour around the monopile foundation of a Darrieus-type tidal current turbine [40]. Their results show that the scour depth is inversely correlated with the tip-bed clearance between the turbine and seabed. Empirical equations are also proposed for the prediction of the temporal scour depth around the turbine, although this has not been extensively verified.

Wang et al. Experimental Investigation of Local Scour Protection for Cylindrical Bridge Piers Using Anti-Scour Collars

The authors conduct live-bed pier scour experiments to investigate the effects of collars as a scour countermeasure [41]. Three variables, namely the collar installation height, collar external diameter, and collar protection range, are tested. Important design guidelines such as the recommended collar shape, installation height, and collar diameter are provided.

Wei et al. Vortex Evolution within Propeller Induced Scour Hole around a Vertical Quay Wall

This study advances the technique of oblique particle image velocimetry (OPIV) to conduct a detailed experimental study on the flow field in a scour hole induced by a propeller, including the effect of a vertical quay wall [42]. Concurrent measurements of scour and flow during the temporal development of the scour hole are performed successfully. The evolution of the vortex system and its interaction with the developing scour hole are examined in detail, elucidating the distinct influence of different quay types on the formation of flow patterns and the resulting scour profiles. The near-bed flow characteristics that are indicative of the erosive flow mechanisms are discussed; this provides new insights into the scour mechanism associated with the development of the scour hole. 
Williams et al. Examination of Blockage effects on the Progression of Local Scour around a Circular Cylinder

This paper describes investigations of the effect of the blockage ratio, which is defined as the ratio of pier diameter and flume width, on scour around a circular cylinder [43]. Unlike past researchers who stated how such effects are negligible when the blockage ratio exceeds 0.1 and 0.125 for clear-water and live-bed conditions, respectively, they concluded that the effect also is related to the relative coarseness, which is defined as the ratio of pier diameter and median grain size of the bed sediment. It suggests that further experiments are needed for the range of relative coarseness ratios exceeding 100 in order to establish the role of blockage ratio effects to refine existing scour estimation methods.

Yang et al. Local Scour at Complex Bridge Piers in Close Proximity under Clear-Water and Live-Bed Flow Regime

This experimental study investigates the characteristics of scour at complex bridge piers in close proximity under both clear-water and live-bed flow regimes [44]. The results are compared with those for a single complex pier. A different scour pattern is observed when more than one complex pier with variable arrangements is present. Moreover, the resulting scour pattern also is different for clear-water and live-bed conditions, with an important influence of migrating bed forms on scour under the latter condition.

\section{Conclusions}

This Special Issue presents up to date research on scour following experimental, numerical, and field approaches covering the interaction of the flow and sediment bed around different structures such as bridge piers, monopiles, propellers, turbines, weirs, grade-control structures, and pipelines. The majority of the papers examined the subject from the empirical or experimental approach (64\%); the others are founded on the numerical and field approaches, and a review paper. The leading group of papers was that devoted to the pier scour, with five papers or $36 \%$. The review paper summarizes research works to-date relating to bridge foundations, namely piers and abutments, in supercritical flows. The number of papers published in terms of the research methodology or structure type, namely the experimental approach and pier scour, respectively, are representative of the number of papers most commonly found within scour research in archival journals and conference proceedings. Notwithstanding the number of published research works in a particular area, this does not negate the importance of scour research in the other areas and research approaches.

Author Contributions: All three writers contributed equally in the preparation and writing of the paper. All authors have read and agreed to the published version of the manuscript.

Funding: This research received no external funding.

Conflicts of Interest: The authors declare no conflict of interest.

\section{References}

1. Whitehouse, R.J.S.; Harris, J.M.; Sutherland, J.; Rees, J. The nature of scour development and scour protection at offshore windfarm foundations. Mar. Pollut. Bull. 2011, 62, 73-88. [CrossRef] [PubMed]

2. Fredsøe, J. Pipeline-seabed interaction. J. Wtrw. Port Coast. Ocean Eng. ASCE 2016, 142, 03116002. [CrossRef]

3. Guan, D.; Chiew, Y.M.; Melville, B.W.; Zheng, J. Current-induced scour at monopile foundations subjected to lateral vibrations. Coast. Eng. 2019, 144, 15-21. [CrossRef]

4. Sumer, B.; Fredsøe, J. Scour below pipelines in waves. J. Wtrw. Port Coast. Ocean Eng. ASCE 1990, 116, 307-323. [CrossRef]

5. Chiew, Y.M. Mechanics of local scour around submarine pipelines. J. Hydraul. Eng. ASCE 1990, 116, 515-529. [CrossRef]

6. Liang, D.; Cheng, L. A numerical model for wave-induced scour below a submarine pipeline. J. Wtrw. Port Coast. Ocean Eng. ASCE 2005, 131, 193-202. [CrossRef] 
7. Fuhrman, D.R.; Baykal, C.; Sumer, B.M.; Jacobsen, N.G.; Fredsøe, J. Numerical simulation of wave-induced scour and backfilling processes beneath submarine pipelines. Coast. Eng. 2014, 94, 10-22. [CrossRef]

8. Fredsøe, J.; Hansen, E.A.; Mao, Y.; Sumer, B.M. Three dimensional scour below pipelines. J. Offshore Mech. Arct. Eng. 1988, 110, 373-379. [CrossRef]

9. Cheng, L.; Yeow, K.; Zhang, Z.; Teng, B. Three-dimensional scour below pipelines in steady currents. Coast. Eng. 2009, 56, 577-590. [CrossRef]

10. Wu, Y.S.; Chiew, Y.M. Three-dimensional scour at submarine pipelines. J. Hydraul. Eng. ASCE 2012, 138, 788-795. [CrossRef]

11. Chen, B.; Cheng, L. Numerical investigations of three-dimensional flow and bed shear stress distribution around the span shoulder of pipeline. J. Hydrodyn. 2004, 16, 687-694.

12. Li, F.Z.; Dwivedi, A.; Low, Y.M.; Hong, J.H.; Chiew, Y.M. Experimental investigation on scour under a vibrating catenary pipe. J. Eng. Mech. ASCE 2013, 139, 868-878. [CrossRef]

13. Hsieh, S.C.; Low, Y.M.; Chiew, Y.M. Flow characteristics around a circular cylinder subjected to vortex-induced vibration near a plane boundary. J. Fluids Struct. 2016, 65, 257-277. [CrossRef]

14. Guan, D.; Hsieh, S.C.; Chiew, Y.M.; Low, Y.M. Experimental study of scour around a forced vibrating pipeline in quiescent water. Coast. Eng. 2019, 143,1-11. [CrossRef]

15. Guan, D.; Hsieh, S.C.; Chiew, Y.M.; Low, Y.M.; Wei, M. Local scour and flow characteristics around pipeline subjected to vortex-induced vibrations. J. Hydraul. Eng. ASCE 2020, 146, 04019048. [CrossRef]

16. Tofany, N.; Low, Y.M.; Lee, C.-H.; Chiew, Y.M. Two-phase flow simulation of scour beneath a vibrating pipeline during the tunnel erosion stage. Phys. Fluids 2019, 31, 113302. [CrossRef]

17. Hamill, G.A. Characteristics of the Screw Wash of a Manoeuvring Ship and the Resulting Bed Scour. Ph.D. Thesis, Queen's University Belfast (United Kingdom), Belfast, UK, 1987.

18. Wei, M.; Chiew, Y.M. Characteristics of propeller jet flow within developing scour holes around an open quay. J. Hydraul. Eng. 2018, 144, 04018040. [CrossRef]

19. Lai, J.S.; Chang, F.J. Physical modeling of hydraulic desiltation in Tapu Reservoir. Int. J. Sediment Res. 2001, $16,363-379$.

20. Wang, H.W.; Kondolf, G.M.; Desiree, T.; Kuo, W.C. Sediment management in Taiwan's reservoirs and barriers to implementation. Water 2018, 10, 1034. [CrossRef]

21. Bormann, N.E.; Julien, P.Y. Scour downstream of grade-control structures. J. Hydraul. Eng. ASCE 1991, 117, 579-594. [CrossRef]

22. Shen, H.W.; Lai, J.S. Sustain reservoir useful life by flushing sediment. Int. J. Sediment Res. 1996, 11, 10-17.

23. Kondolf, G.M.; Gao, Y.X.; Annandale, G.W.; Morris, G.L.; Jiang, E.H.; Zhang, J.H.; Cao, Y.T.; Carling, P.; $\mathrm{Fu}$, K.D.; Guo, Q.C.; et al. Sustainable sediment management in reservoirs and regulated rivers: Experiences from five continents. Earth's Future 2014, 2, 256-280. [CrossRef]

24. Annandale, G.W.; Morris, G.L.; Karki, P. Extending the Life of Reservoirs: Sustainable Sediment Management for Dams and Run-of-River Hydropower; World Bank Group: Washington, DC, USA, 2016.

25. Stähly, S.; Franca, M.J.; Robinson, C.T.; Schleiss, A.J. Sediment replenishment combined with an artificial flood improves river habitats downstream of a dam. Nat. Sci. Rep. 2019, 9, 5176. [CrossRef] [PubMed]

26. Okano, M.; Kikui, M.; Ishida, H.; Sumi, T. Reservoir sedimentation management by coarse sediment replenishment below dams. In Proceedings of the Ninth International Symposium on River Sedimentation, Yichang, China, 18-21 October 2004; pp. 1070-1078.

27. Sumi, T.; Kantoush, S.A. Sediment replenishing measures for revitalization of Japanese rivers below dams. In Proceedings of the 34th IAHR World Congress, Brisbane, Australia, 26 June-1 July 2011; pp. 2838-2846.

28. Ock, G.; Sumi, T.; Takemon, Y. Sediment replenishment to downstream reaches below dams: Implementation perspectives. Hydrol. Res. Lett. 2003, 7, 54-59. [CrossRef]

29. Battisacco, E.; Franca, M.J.; Schleiss, A.J. Sediment replenishment: Influence of the geometrical configuration on the morphological evolution of channel-bed. Water Resour. Res. 2016, 52, 8879-8894. [CrossRef]

30. Kondolf, G.M. Sediment management at the river-basin scale: Challenges and opportunities. In Proceedings of the 3rd International Workshop on Sediment Bypass Tunnels, Taipei, Taiwan, 9-12 April 2019.

31. Chavan, R.; Gualtieri, P.; Kumar, B. Turbulent flow structures and scour hole characteristics around circular bridge piers over non-uniform sand bed channels with downward seepage. Water 2019, 11, 1580. [CrossRef]

32. Cui, Y.; Lam, W.H.; Zhang, T.; Sun, C.; Hamill, G. Scour induced by single and twin propeller jets. Water 2019, 11, 1097. [CrossRef] 
33. Guan, D.; Liu, J.; Chiew, Y.-M.; Zhou, Y. Scour evolution downstream of submerged weirs in clear water scour conditions. Water 2019, 11, 1746. [CrossRef]

34. Lee, F.-Z.; Lai, J.-S.; Guo, W.-D.; Sumi, T. Scouring of replenished sediment through reservoir flood discharge affects suspended sediment concentrations at downstream river water intake. Water 2019, 11, 1998. [CrossRef]

35. Lin, Y.-B.; Lin, T.-K.; Chang, C.-C.; Huang, C.-W.; Chen, B.-T.; Lai, J.-S.; Chang, K.-C. Visible light communication system for offshore wind turbine foundation scour early warning monitoring. Water 2019, 11, 1486. [CrossRef]

36. Link, O.; Mignot, E.; Roux, S.; Camenen, B.; Escauriaza, C.; Chauchat, J.; Brevis, W.; Manfreda, S. Scour at bridge foundations in supercritical flows: An analysis of knowledge gaps. Water 2019, 11, 1656. [CrossRef]

37. Ma, X.; Wang, L.; Nie, R.; Yang, K.; Liu, X. Case study: Model Test on the effects of grade control datum drop on the upstream bed morphology in Shiting River. Water 2019, 11, 1898. [CrossRef]

38. Mathieu, A.; Chauchat, J.; Bonamy, C.; Nagel, T. Two-phase flow simulation of tunnel and lee-wake erosion of scour below a submarine pipeline. Water 2019, 11, 1727. [CrossRef]

39. Quezada, M.; Tamburrino, A.; Niño, Y. Numerical study of the hydrodynamics of waves and currents and their effects in pier scouring. Water 2019, 11, 2256. [CrossRef]

40. Sun, C.; Lam, W.H.; Lam, S.S.; Dai, M.; Hamill, G. Temporal evolution of seabed scour induced by darrieus-type tidal current turbine. Water 2019, 11, 896. [CrossRef]

41. Wang, S.; Wei, K.; Shen, Z.; Xiang, Q. Experimental investigation of local scour protection for cylindrical bridge piers using anti-scour collars. Water 2019, 11, 1515. [CrossRef]

42. Wei, M.; Cheng, N.-S.; Chiew, Y.-M.; Yang, F. Vortex evolution within propeller induced scour hole around a vertical quay wall. Water 2019, 11, 1538. [CrossRef]

43. Williams, P.; Balachandar, R.; Bolisetti, T. Examination of blockage effects on the progression of local scour around a circular cylinder. Water 2019, 11, 2631. [CrossRef]

44. Yang, Y.; Melville, B.W.; Macky, G.H.; Shamseldin, A.Y. Local scour at complex bridge piers in close proximity under clear-water and live-bed flow regime. Water 2019, 11, 1530. [CrossRef]

(C) 2020 by the authors. Licensee MDPI, Basel, Switzerland. This article is an open access article distributed under the terms and conditions of the Creative Commons Attribution (CC BY) license (http://creativecommons.org/licenses/by/4.0/). 